\title{
Political economy of the Stability and Growth Pact
}

\author{
Orsola Costantini* \\ Institute for New Economic Thinking, New York, NY, USA
}

In spite of many claims that the European treaties cannot be reformed, European economic governance has evolved substantially over the last two decades. The process has erected an ever more complex system of rules, deadlines, and commitments conferring more power on the European Commission and other common institutions. This paper analyses the sequence of reforms to the Stability and Growth Pact, focusing on how reliance on shaky theory-laden macroeconomic estimates has played a crucial role in the whole process. The cyclically adjusted (or structural) budget estimate has provided scientific validation to behind-the-scenes political negotiations.

Keywords: European Union, eurozone, cyclically adjusted budget, fiscal policy, structural reforms

JEL codes: $E 6, E 62, H 6, H 68, N 4$

\section{INTRODUCTION}

As of 2015, after an intense period of legislative innovation, the European economic governance system is a complex system of rules, deadlines, and commitments supervised by the European Commission. This evolution is the result of the interaction of two movements: first, the desire of the Maastricht architects to reduce the autonomous role of national democratic governments and the Keynesian welfare state; second, the power of traditional national and bureaucratic forces, unsympathetic to anything resembling true political union. The most obvious expression of the first movement was the foundation of the European Central Bank (ECB) as an independent institution, prevented from directly financing the member states. This obliterated the space for the state to enact appropriate public policies, independent of the whims of the financial markets. ${ }^{1}$ The second movement is recognizable in the original intergovernmental character of the European Union (EU) political institutions, such as the Council.

Sometimes the goals of these two forces converged; at other times they have opposed one another. This paper reconstructs their dialectical interaction since the 1992 Maastricht Treaty: a movement, as Kindleberger (1996) would call it, between centralization and pluralism. Looking especially at the reforms of the Stability and Growth Pact (SGP), the paper focuses on the crucial role played by the cyclically adjusted (or structural) budget estimate.

Section 2 starts with a brief description of the Maastricht process, as the result of the common agenda of these two forces. Then, it proceeds to the first reform of the SGP in 2005.

* I would like to thank Professors Mario Seccareccia and Marc Lavoie for their support and advice, and two anonymous referees for useful comments.

1. Recently, this point has been reiterated by Lavoie (2015) and Seccareccia/Correa (2015).

Received 8 July 2016, accepted 28 July 2017 
At that time, the second movement - that is, the idea of the Union as an assembly of sovereign nations - appeared to gain strength. In fact, the relaxation of some fiscal constraints and the allowance for several budget exceptions aimed at reducing the power of the Commission and increasing the room for maneuver of the member countries. The contextual redefinition of the fiscal rule from a nominal target into a structural budget estimate showed how much austerity at the time was a common desire: reliance on shaky theoryladen estimates was supposed to give countries sufficient flexibility for ad hoc solutions, while retaining the disciplinary effect of the external rule on the national electorates.

Hence, Section 3 takes a break from the historical reconstruction of the European unification process to focus on the economic and political content of the estimate as it developed over time. In fact, the opportunistic use of economic estimates as policy rules is not a recent finding: it is in line with a tradition that goes back to the 1940s, when the predecessor of the cyclically adjusted budget, the high employment budget, was conceived in the US context (Costantini 2015). Then, as well as today, budget rules were found to ease the management of a change when one power bloc desires to implement policies that do not command democratic support.

In the EU, the ability of the cyclically adjusted budget to throw a cloak of spurious statistical precision over any mix of cross-pressures and interests makes it a near-perfect policy instrument for managing conflicts and negotiations, neutralizing the role of national electorates. Moreover, because its formula involves consideration of the effects of the various measures on prospective as well as potential output, its adoption was the first step that transformed the European Economic Governance into a system that has a much deeper control on national economic policies.

Section 4 applies these concepts to the further evolution of the Economic and Monetary Union (EMU), where, in spite of the initial intergovernmental inspirations, the absence of active convergence policies, coupled with a one-size-fits-all monetary policy, encouraged divergent economic dynamics among countries. The combination of financial deregulation, fiscal austerity, and the ECB's policy restrictions further eroded national sovereignty, eventually threatening the whole edifice, as we are witnessing now. When the 2008 crisis burst, the power of creditors increased enormously. The new fiscal rules that had appeared as a guarantee of flexibility and symmetric treatment, in the absence of policies aimed at correcting regional disparities, became an instrument of disclosed resolution of the tensions arising from asymmetric power distribution, always appearing as scientifically objective.

Arguably, this has reinforced a movement toward the centralization of power away from most national centers and away from a symmetrical intergovernmental structure. The 2011-2012 pact reforms intensified the power of the Commission, which has dramatically determined the policy agenda in most EMU countries, pushing for labor-market and pension reforms as well as systematic changes in the tax structure designed to increase the weight of regressive consumption taxation. A further weapon of enforcement of the Commission's prescription is the conditionality of the ECB's support to the member countries. But the unstable framework and the political void give enormous power to the Central Bank, which often acts as the arbitrator of fiscal policy.

As an ultimate redefinition of the locus of power and decision-making, the debate has focused recently on whether the EMU should become a fiscal union (Villeroy de Galhau/ Weidmann 2016). But of course counter-factors remain at play. The fracture between the fiscal and the financial authorities causes instability and recurrent emergencies. Given the incompleteness of the EMU framework, only an intergovernmental action can deal with quick legislative innovations. This is the case, for instance, in the role of the Ecofin and of the Eurogroup (an informal institution, which does not exist in the treaties) in the creation of the European Financial Stability Facility and of the European Stability Mechanism. 
While the crisis has most dramatically uncovered the need in European capitalism for a stronger central power, able to react rapidly to economic and financial down-swings with temporary discretionary interventions, it is an open question as to whether a stable but fully flexible institutional and power equilibrium will emerge. The current inherent instability can either fuel or disrupt the process toward a unified solution. But while the evolving structure may eventually heal the fracture between the fiscal and monetary authorities, it also seems to exclude any relevant electoral legitimation.

\section{THE STABILITY AND GROWTH PACT}

The 1992 Maastricht Treaty incarnated a neoliberal vision of European governance that chiefly reflected accords between France and Germany: the Europe of the cercles concentriques. It aimed to liberalize markets, encourage privatization, and make it easier for firms to compete across national boundaries. It removed obstacles to the movement of goods and, far more equivocally, people within Europe.

The Union's governance mechanisms were (and largely remain) more a space for negotiations between political representatives of member countries and other well-organized, powerful groups rather than unified expressions of popular political sentiments and policies. Though it did little to create strong representative institutions - such as the European Parliament, which still lacks the formal power of legislative initiative - the Treaty set down the convergence criteria and defined the path to the creation of the Economic and Monetary Union, informally called the eurozone.

The most important steps were the approval of the Stability and Growth Pact in 1997 that extended the convergence criteria as permanent requirements to maintain the membership, and the creation in 1998 of a powerful independent monetary institution, the European Central Bank and its European System of Central Banks. The ECB was charged by statute with the task of guaranteeing price stability (as well as securing the other objectives of the EU, without prejudice for price stability - a clause that would become crucial later for justifying unconventional emergency measures). The Bank was prohibited from purchasing sovereign bonds on primary markets.

These features were in line with an economic theory developed during the 1980s. Specifically, the theory of central banks' independence built on previous work by Robert Barro and Robert Gordon on inflationary biases, and suggested that independent (and conservative) central banks could attain the inflation target at less cost, thanks to their greater credibility in pursuing the objective. Similarly, the literature on public choice prescribes that governments follow a rule-based fiscal policy, which would provide guarantees of their anti-inflationary commitment to the financial markets.

Structural change along these lines had been partly anticipated in Italy and in France not in Germany - by the separation of the Treasury from the central banks that occurred respectively in 1981 and $1993 .{ }^{2}$ But, interestingly, the idea and logic behind both institutional arrangements can be traced much further back, to the authoritarian intellectual movements of the French Traditionalists and the German Ordoliberals. ${ }^{3}$

2. In Italy the separation long preceded the moves by other countries. The initiative came from Secretary of Treasury Nino Andreatta, who was then dealing with a banking scandal involving the Vatican and various illegal associations.

3. In particular, Alain Parguez (2016) notes that the establishment of the ECB was consistent with the plans for European integration developed after the First World War and into the Second by the conservative economists and financial experts linked to the French Traditionalist 
On the eve of the creation of the EU, the contextual enactment of the new monetary and fiscal frameworks revealed itself to be crucial. In fact, the rupture of the linkages between governments and national central banks was a strong incentive to maintain austere budget policies but was no real guarantee of the prospective sustainability of public debts and convergence of public policies, which were regarded as key to the success of the project. While other options were under study, finance minister Theo Waigel began a campaign to codify the rules and procedures of EU fiscal sovereignty as early as 1995.

The agreement on the SGP, finally achieved in 1997, led to a fiscal rule formulated in terms of actual budget balance, leaving the composition of the budget to each individual country, as long as the difference between total expenditures and total outlays conformed to the guideposts: the importance of this qualification will become clear below. As is well known, the accord defined ceilings for both budget imbalances and individual country total debt loads (3 percent and 60 percent of GDP respectively). The accord also committed member states to an official Medium Term Objective of sustaining fiscal positions close to balance or in surplus (CTBOIS) and set up a formal procedure to enforce this. In this framework the cyclically adjusted budget estimate appears for the first time, as one among other tools to assess the prospective soundness of a country's fiscal position.

The process required individual countries to submit their fiscal plans to the European Commission for advance approval. If the European Commission disapproved, it was empowered to issue official preventive warnings. If these proved unavailing, the European Commission could propose initiating a formal Excessive Deficit Procedure (EDP). But the latter could only be authorized by the Economic and Financial Affairs Council (Ecofin, the council of finance ministers of all the member states of the EU). Within the Procedure, culprits were afforded a certain amount of time (originally one year, later up to five years) to adjust, and only in extreme cases could incur monetary fines.

The unspoken idea was that deregulated private capital markets together with fiscal rules would by themselves discipline the countries' convergence. The ECB and the TARGET2 payment system were designed to allow perfect capital mobility and symmetric access to the financial markets, under the assumption that price movements would grant perfect asset substitutability. The SGP would grant efficacy to the inflation-targeting strategies of the central bank.

From the beginning of the process, many economists warned of the deflationary bias of the project and against the complete absence of concern for employment levels. ${ }^{4}$ A long series of efforts by Keynesian economists and some policy-makers to provide the

movement: François Perroux, Jean Monnet, and Jacques Rueff. Perroux published a final version of his plan for Europe in 1943, suggesting that the governments should be deprived of the ability to create money, as a guarantee against a strong (republican) state and to reinstate a genuine social order and avoid the uncontrolled diffusion of the welfare state. Similarly, the idea of a politically neutral Central Bank is consistent with the Ordoliberal ideology. The Ordoliberals understood the importance of institutional settings to create a stable economic system, respectful of natural social order (Ptak 2009). This critique derived from an analysis of the total state by Carl Schmitt (1931 [2015]): 130; see also Vinx 2015: 10): parliamentarian democracy had eliminated the role of the state and politics as super partes arbitrators. Classical liberalism, according to them, had given too much space to the unleashed forces of the market to shape the political and economic playground. Instead, they aimed at integrating the market into a social order, intended as a mix of hierarchy and meritocracy through competition, and reflecting a religious ethics. The guardian of such a framework must be a strong political power, detached and above special interests and economic lobbies: hence, not an expression of popular sentiment.

4. Too many to give an exhaustive list, but see for instance Godley (1992), Goodhart (1998), Parguez (1999), and Simonazzi/Vianello (1999). 
Union with some sort of insurance scheme was doomed by nationalistic fears coupled with anxieties about rising inflation and public budgets (European Commission 1993; Holland/ Varoufakis 2011; Holland 2014). But proposals for a single issuance of public debt came also from less progressive stand-points, as mere stability mechanisms aimed at improving financial integration (Giovannini Group 2000).

Within a general view about the desirability of weakening the Keynesian state, concerns about the overall stability of the system were overlooked. Eventually, if the arrangement would prove insufficient, a crisis would force the member countries into further action - as Monnet appears to have predicted. ${ }^{5}$

What really mattered to national elites at the time was to obtain a guarantee of price stability that could help the EU to become an international financial center (mainly a French aspiration) and help the attainment of current-account surpluses. In this regard, Germany benefited the most from a relatively undervalued currency. As pointed out by Joseph Halevi (Bellofiore/Halevi 2011; Halevi 2016), this setting reflects a typical pattern in the trade relations within Europe since the 1960s. In fact, as wage increases failed to be coordinated (France in 1968-1971, Italy in 1970-1975, Germany in 1970-1972), countries perceived them as affecting their economic performance, expressed by external surpluses. Hence they invariably adopted stop-go deflationary and neo-Mercantilist policies to induce a correction in their external position, even if that meant reducing their current or prospective growth rates.

Since the first monetary experiments in 1972 and 1979, many industrial sectors appear to have counted on recessions and pressures for convergence as a means to roll back wage demands and unionization as they restructured and outsourced. This was still valid at the time of the Maastricht Treaty. In addition, for the industries in peripheral countries such as Spain and Ireland, a new age of enhanced access to the financial markets and capital inflows opened up. The first crisis occurred in 2001 and brought about a rather weak reform of the European institutions, but one that would have important consequences, as we witness today.

In 2002, when the euro, which had existed in the virtual markets since 1998, finally became available to ordinary citizens, many European countries were struggling to comply with the official constraints: requests for relaxation of budgetary constraints multiplied, preparing the ground for a reform of the SGP. The Ecofin and the Commission quickly broke ranks, as ministers proved reluctant to follow up on the Commission's recommendations for warnings. Ecofin was also far more amenable than the Commission to winding down infraction proceedings on the basis of mere promises to do better. The conflict went so far that the Commission, in 2004, brought suit against Ecofin at the European Court of Justice for suspending Pact rules in the cases of Germany and France. ${ }^{6}$

As Excessive Deficit Procedures proliferated, member countries facing official or unofficial reprimands sought to justify their positions. Not surprisingly, many appealed for adjustments recognizing special circumstances. For example, the rule made no distinctions among types of spending; it did not distinguish between outlays for investment or consumption. As criticism of the 3 percent ceiling spread (Blanchard/Giavazzi 2004), countries also justified expansionary fiscal measures by asserting that their previous cyclically adjusted budget estimates had not envisaged the sudden stop in their economy and the consequent fall in tax revenues. They claimed to be following fiscal plans projecting that the high growth rates experienced up to 2001 would continue. Consequently, they disavowed responsibility for

5. As he wrote in his Mémoires (Monnet 1976).

6. The Commission won the case and an Excessive Deficit procedure was opened for France and Germany, only to be rapidly closed by the Commission itself. 
excessive deficits and insisted that they should be allowed to spend more to fight the unexpected recession.

Detailed analyses of the various country national budgets based on actual balance-sheet entries indicate that many cyclically adjusted budget projections were indeed of poor quality (Larch/Turrini 2009; Truger 2014). The reasons for bad performance were diverse and not all were favorable to the countries' cases. But they should have been foreseeable from the econometric debates of the 1980s: potential output turned out to be lower than expected when fiscal plans were formulated; postulated tax elasticities repeatedly failed to reflect recent changes in the law, etc.

In addition, many countries had embraced short-term fixes such as sales of public assets and even more elaborate forms of financial engineering precisely to escape the constraints (European Commission 2004). At the time, most of these received little publicity.

Instruments developed by Goldman Sachs, JP Morgan Chase and a wide range of other banks enabled politicians to mask additional borrowing in Greece, Italy and possibly elsewhere. In dozens of deals across the Continent, banks provided cash upfront in return for government payments in the future, with those liabilities then left off the books.... Critics say that such deals, because they are not recorded as loans, mislead investors and regulators about the depth of a country's liabilities. (Story et al. 2010)

In Italy, such deals were pursued extensively during the period when Mario Draghi was Director-General of the Italian Treasury (1991-2001) (Lucarelli 2015). The effects of this heavy reliance on external speculative finance would emerge dramatically some years later.

Despite claims that the inaccuracy of the estimate was part of the problem, the cyclically adjusted budget turned out to be an important part of the solution. In November 2002, the EU institutions agreed to re-express the SGP's provisions in its terms (European Commission 2002). Simultaneously the Commission dramatically altered the estimation method: the 'statistical' approach relying on a statistical filter based on the Hodrick-Prescott method (the HP filter) gave way to calculations relying on production functions (Larch/Turrini 2009).

But discussions did not stop there. Against a revision of the Pact were the Commission and several national members, including the Netherlands, Austria, and Luxembourg, whose prime minister at the time happened to be one Jean-Claude Juncker. German Chancellor Gerhard Schroeder also faced determined opponents within his own government, notably Finance Minister Hans Eichel. As a leaked German government memo from the end of August 2004 revealed, the Chancellor and his allies 'found fault with Eichel for being "critical of increasing the flexibility" of the Pact. Eichel, the memo indicated, wanted to preserve the pact "as a disciplinary tool against individual ministries" the idea being that he could force budgetary responsibility by claiming that his hands were tied by Brussels' (Reiermann/Wiegrefe 2012).

The 2005 reform of the SGP (European Commission 2005a) resolved these clashing viewpoints through yet another political compromise. Time for adjustment was prolonged; but Schroeder's effort to terminate the Commission's role failed. A complete list of exceptions was not drafted, but there was explicit mention of various factors that might permit Medium Term Objectives to diverge from narrow bounds in the SGP. These included the need for public investments; the necessity for member states to pursue their efforts to implement structural reforms related to the aging of their populations as well as increasing employment and labor-force participation ratios; the prevailing cyclical conditions; the implementation of policies related to the Lisbon agenda; and the impact of $\mathrm{R} \& \mathrm{D}$ and innovation. Special consideration was given to budgetary efforts towards 
pension reforms and increasing or maintaining at a high level financial contributions to fostering international solidarity and to achieving European policy goals, notably the unification of Europe if it has a detrimental effect on the growth and fiscal burden of a Member State' (European Council 2005: annex II, 34). This last specification was a contorted way to include - or rather exclude from cyclically adjusted budget computation German fiscal transfers to its new Eastern territories.

Finally, this more elastic version of the SGP confirmed and extended the redefinition of all the fiscal targets in structural terms and added a principle of conditionality allowing excessive deficit procedures to be contingent on the retroactive recalculation of potential output as well as on country-specific structural aspects (ibid.).

The Pact reform was perceived by many as a device for formally maintaining the constraints while at the same time substantially eroding them. It thus absorbed dissent towards the policy via the creation of an open-ended solution that, in dire cases in the future, would be handled by still more ad hoc exceptions. As the former Deputy Finance Minister for Greece, Peter Doukas, told the BBC News, 'The view was that, ok, if the big boys won't adhere and impose discipline on themselves, they're going to be more relaxed in enforcing the treaty [on us]' (Little 2012).

But, paradoxically, the promise of escape hatches in emergencies points to the degree to which the call for austerity reflected shared elite convictions, rather than representing simply an imposition of one country upon the others (for example: Germany) or dictates of technocrats. Portugal, with Prime Minister Barroso, and Spain, with Prime Minister Aznar, as well as Belgium and the Netherlands, were in a position to refuse the austerity reforms suggested by the Commission - simply by taking advantage of the opportunity opened up by the bigger countries.

They did not, however, refuse them. Instead, some of the smaller countries persuaded themselves that maintaining the Commission's powers would provide a long-run guarantee of equal and symmetric implementation of the rules across the Union, neglecting the effects that the policies they were implementing and the framework they were validating would have on the real distribution of power within (and on) the EU. The fact that many peripheral countries (Spain and Ireland above all) were booming, fueled by relatively cheap incoming financial flows from France and Germany, likely facilitated this misjudgment. The positive economic numbers made it easy for these governments to brush off domestic objections to full-throated deregulation of the labor market, privatization, and social spending cuts - always in the name of Europe.

The impression of enhanced statistical precision of the new procedures captured the imaginations of many observers, while the multitude of possible adjustments and exceptions satisfied truly attentive elites. As a consequence the European political establishment mostly lauded the new compromise. But the new procedures also widened the scope for 'technical' judgments by the Commission in ways that only a more accurate analysis of the estimate reveals.

\section{THE CYCLICALLY ADJUSTED BUDGET: HOW TO RIGIDLY IMPLEMENT A FLEXIBLE THEORY PRESCRIPTION}

The cyclically adjusted budget estimate has animated an 80-year-long discussion of fiscal theory and practice. Its function and method of estimation have changed radically over the course of time, responding to different impulses. But regardless of the political view that its construction has reflected in the various circumstances, the cyclically adjusted budget has always served the idea that contingent political matters can be prevented from 
intruding in fiscal policy decisions, for instance by lending itself to mechanical applications of budgetary targets and fiscal soundness criteria.

Today's cyclically adjusted budget estimates are rather different from their predecessors and notably from the high-employment budget of the 1940s and the full-employment surplus that Kennedy's Council of Economic Advisers produced over the 1960s and made into a symbol of the American Keynesian thinking in fiscal policy (Canterbery 1968; Costantini 2015; 2018).

The high-employment budget was developed and promoted by a business group, the American Committee for Economic Development (CED), and was explicitly designed as a budget-targeting device that precluded discretionary fine-tuning of the economy. For this group, expression of the pro-free-trade capital bloc, relying on automatic stabilizers and on a stable budget structure based on technical, professional, objective reasoning, was a way to reduce the risk of political confrontation over fiscal policy and thus reduce the risk of adverse political outcomes, in the politically turbulent 1940 s and early 1950s.

Their budget plans (and rule) published in 1944 and 1947 could yield a surplus at a level of income consistent with high employment of labor. They argued that budget balance could be achieved at any level of national income, but that if the target were fixed at levels much below high employment,

the budget would exert a repressive force upon the economy in depressed conditions, as it did in the 1930s, and would itself contribute to unemployment and a low level of income. While such a program is conceivable, it is certainly not a satisfactory solution to the problem of the debt, and it is unlikely that such a program could survive the pressures that mass unemployment would create, as past experience has shown. (CED 1947: 32)

By liberating high-employment policies from the stigma of socialism and, at the same time, defanging them of their socialist potential, the Committee contributed to setting the conditions for the automatic rules to be redundant, as soon as the political situation stabilized, leading to the Democratic economic policy of the 1960s.

As its denomination suggested, the full-employment surplus was meant to make the public realize the potential of fiscal stimulus for growth, while reassuring them about the consequences for price and budget stability. But, really, in the 1960s it was a convenient communication tool, rather than an engine of analysis:

The public seems to need a number, traditionally a budget deficit, to view with pride or alarm as the case may be. [Unfortunately,] whenever one attempts to reduce a multidimensional concept like the influence of the Government on aggregate economic activity - to a single dimension, index number problems inevitably arise. ... However, the political realities of the day seem to dictate settling on a single index to measure the overall expansionary or contractionary effect of any proposed tax and expenditure program. (Blinder/Solow 1974: 8)

In the 1970s, as control of inflation became an overriding priority of American elites, the methods of estimation began to be questioned. By the 1980s, the methods for estimating the cyclically adjusted budget underwent major changes, reflecting the new priorities. Statistical methods for smoothing out peaks and troughs from actual output grew in popularity as potential output came to be progressively understood as a supply-determined, long-term concept, determining actual output through movements of prices and expectations. Those sorts of moving averages of output were then identified with the trend estimate of actual output, the latter being identified with the economy's potential. This reflected the partial incorporation through Monetarism of an emerging economic doctrine with more radical anti-state implications, signaling the definitive irrelevance of Keynesian attempts to compromise and leaving 
virtually no room for an activist policy consensus. The cyclically adjusted budget became a tool for budget surveillance.

Differences internal to the neoclassical school largely disappear in the empirical literature. The estimation methods reduce to two options, which differ in the way they treat potential output: univariate statistical methods and the 'production function' method. Those avoid identifying politically dangerous employment targets and are claimed to be apolitical. But, as Antonella Palumbo (2013) observes, the potential output estimates based on various averaging/de-trending filters of actual output fundamentally reduce to some sort of moving average or, rather, an ex post average of the actual output. In other words, once normality becomes the target, estimates of potential output become ex post ways of justifying the attained levels of growth and employment. The resulting cyclically adjusted budget fails to immediately recognize government efforts to enhance the economy's potential with demand-side policies - such as public investment - and it validates measures that have the opposite effect: downward movements of output due to budget cuts are incorporated into the estimate of potential output, and thus are not recognized as policy failures.

The definition of fiscal policy sustainability produced from these estimates escapes from tautology only if the assumption of a direct relation between output gaps and changes in inflation holds true. However, as a large literature testifies, no empirical support can be provided for those claims (see for instance Galbraith 1997; Palumbo 2013). Instead, if productive resources and productivity are recognized as affected by the level of activity and by aggregate demand, one can show that restrictive fiscal policy may instead have a perverse effect on public deficits and that, contrarily, expansionary fiscal policy can reduce the ratio of public debt to output (Storm/Naastepad 2012; Ciccone 2013; Thirlwall 2014; Garbellini 2015).

Various versions of purely statistical methods proliferated, but especially common today is the use of the Hodrick-Prescott filter (Hodrick/Prescott 1981), a technique that was first proposed by a mathematician in 1923, but gained widespread implementation in economics only in the late 1990 s. $^{7}$ This filter minimizes deviations of actual from potential output and of the potential rate of growth from a regular trend and contains a stochastic component, so that it follows quite closely the actual path of the economy. This means that the corresponding cyclically adjusted budget cannot accurately distinguish between automatic and discretionary movements of the budget, and becomes just a tool for budgetary trend surveillance. But its use as a fixed target and policy guideline is complicated by the fact that deviations from trend are designed to average to zero over the sample. This property is responsible for an end-of-sample bias, where the level of the trend tends to be over- or under-estimated to compensate for the asymmetric behavior of the deviations in the rest of the sample. The estimates are therefore inaccurate where it matters the most - that is, at the end of the sample - and require repeated revisions.

The HP filter and similar tools became popular in part because their application has the advantage of being simple and time saving, thanks to now easily available statistical software and because they do not require the collection of a large amount of data. But they are insensitive to structural breaks and other country-specific institutional characteristics.

This is where the so-called production function approach comes to the rescue. This method emerged around the same time as the purely statistical ones but spread more slowly. The IMF seems to have pioneered the method; the first attempt goes back to 1977 (De Masi 1997). Numerous versions of this approach exist. Virtually all begin by describing potential output in terms of a Cobb-Douglas production function. They are

7. Multivariate filters are also used to estimate potential output but not, to my knowledge, for the cyclically adjusted budget. 
thus subject to all the problems that attend this celebrated construction, especially the concept of total factor productivity (Sylos Labini 1995; Pasinetti 2000; Felipe/McCombie 2007; 2013). ${ }^{8}$ Moreover, the variables entering the production function are often themselves estimates, obtained by applying the usual filters. Therefore, they are not exempt from the end-of-sample bias and zero sample-mean restrictions that make the previously described method so inappropriate.

Foremost among these, perhaps, is the way the approach estimates the non-accelerating inflation (or wages) rate of unemployment (the NAIRU and NAWRU). Put simply, efforts to estimate it empirically beg all the important questions and in practice break down. The long list of failed attempts has gradually led to changes in its definition: from being considered a fixed rate it became a variable moving with the rest of the economy. The rationale behind the new interpretation is that if a negative shock occurs, the unemployment rate will likely rise, changing its relation to inflation. Thus it is most commonly estimated by statistical filtering. However, this does not solve the crucial problem that the data do not reveal a reliable correlation between unemployment gaps and changes in inflation (or in unit labor costs, in the NAWRU (Havik et al. 2014)). For this reason, most econometricians employ multivariate instead of univariate filters, because they permit the imposition of some constraints on the form of the estimate, namely a Phillips curve type of relation, that otherwise would not emerge. The triviality of these exercises is discussed by many authors (including Galbraith 1997; Gordon 1997; Storm/Naastepad 2012). As Palumbo (2013: 103) summarized: 'Even if there is no such explicit hypothesis ..., the estimated NAIRU is built so to absorb all the changes in the average level of the actual unemployment rate, automatically attributing them to supposed changes in the supply factors determining the NAIRU.'

In the Commission's formula, the NAWRU is obtained from a Kalman filter estimate, under the assumption of a Phillips curve relationship, that is, that the unemployment gap is negatively related to the change in wage inflation. The unemployment gap takes the form of an autoregressive process of the second order, assumed stationary and with sample mean of zero. Thanks to the above conditions and to the assumption that normal output cyclically fluctuates around potential, the NAWRU values frequently appear to be close to those of the actual unemployment rate, especially at the end of the sample.

Theoretically speaking, both purely statistical and production function approaches share the logic that economic growth is supply-driven. The production function method, however, permits explicit consideration of those supply-side aspects in the estimate rather than implicitly, as the filters do. This is why this second method appeared more appropriate to the circumstances by the EU Commission. The step reflected also the insistence of member states that the rules discriminate among different types of spending.

The formula for the cyclically adjusted budget used by the Commission is similar to those used by most national and international agencies. The method was decided by the Economic and Financial Affairs group of the European Commission and its extension, the Output Gap Working Group (Havik et al. 2014). A cyclical component of the budget balance is first estimated and subsequently subtracted from the nominal budget. The cyclical component is obtained by applying a budgetary sensitivity parameter $\varepsilon$ to an estimate of the output gap, which is the difference between potential output and actual output.

The potential output is defined by a Cobb-Douglas production function with constant returns to scale and factor price elasticity equal to one. Inputs are: the current capital stock, assuming full capacity utilization, a normal degree of utilization of labor (NAWRU), and a

8. The cyclically adjusted budget has been criticized also by neoclassical economists such as Blanchard (1993) and Fatàs/Mihov (2010). 
normal level of efficiency of factor inputs, with this trend efficiency level being measured using a bivariate Kalman filter model which exploits the link between the total factor productivity cycle and the degree of capacity utilization in the economy.

The reference methodology for the estimation of the sensitivity parameters was developed by the OECD (Girouard/André 2005; Mourre et al. 2014). It takes account of the elasticity with respect to output of the revenues arising from four different sources (personal income taxes, corporate taxes, social security contributions, indirect taxes) and of unemploymentrelated expenditures. The measurement also requires estimates of the distribution of income and the tax rule. Furthermore, the elasticities are computed by approximating the tax basis by wage income in the manufacturing sector, which means that neither the self-employed nor the other sources of income of workers in manufacturing, such as interest income, are taken into account. This might be relevant if, for instance, we think that the interest rate on public bonds is cyclically related.

Such individual elasticities are then weighted according to their share of the total tax burden and on total government outlays. The weighted sum is computed in terms of a reference year, in the case of outlays, or averaged over ten years, in the case of revenues. This latter aspect is consistent with the attempt to detect discretionary deviations within a fixed budget structure, although less justifiable is the fact that the European Commission used, until 2014, the weights computed for the decade 1995-2004.

Nevertheless, due to the difficulty of the calculation process, the individual elasticities are updated very rarely and treated as time-invariant in the meantime: the elasticities that the European Commission used until 2012 were computed in 2005 and based on tax codes of 2003 and data on income distribution collected in 2001. Since the following year, they have been using the updated elasticities, with data up to 2013. Thus, the obvious delay in data availability is such that the deviations in the budget deriving from a change in income distribution connected to the cycle cannot be taken into account (European Commission 2005b; Mourre et al. 2013). Hence, this parameter prevents the cyclically adjusted budget from being a credible indicator of the size of the automatic stabilizers relative to that of the discretionary fiscal measures, regardless of how the potential output is measured.

In conclusion, such estimates fail to provide indicators of the size of the automatic stabilizers and the sustainability of a budget policy. The estimates are very sensitive to time series updates and hence are subject to continuous and significant ex post revision. Especially in the forecasting extensions (see for instance the $T+5$ and $T+10$ methods of EU Ecofin as in Havik et al. 2014), the production function method tries to integrate into the estimate parameters that reflect the institutional aspects of a country, such as the rules defining the various market conditions and even those shaping the political process, such as union density and labor-market taxation and policies. This, paradoxically, opens up the possibility of an even more arbitrary and flexible use of fiscal policy, because the relationship of the latter with output is mediated by the allegedly technical interpretation of the institutional framework of the economy.

In many formulations, in fact, the only way that governments can affect potential output estimates upward is to adapt the institutions to rules specified by the forecaster. Typically, so-called market deregulations are considered to increase the output gap and thus create more room for actual deficit tolerance. Thus the cyclically adjusted budget, instead of indicating how fiscal policy can best obtain the economic objective that a community prefers, becomes a tool for constraining the community's political choices to the demands of a theory on which no consensus exists and which yields sharply different results depending on when and where it is applied.

The creation of an established channel for special interests to enter the policy negotiations appears to be in contrast with the Ordoliberals' prescriptions of constraining any lobbies' 
influences on political power. However, it is worth remembering that both the Traditionalists and the Ordoliberals had in practice strong ties with parts of business and other groups of interest (Ptak 2009: 109; Parguez 2016). Moreover, within all streams of neoliberalism, Ordoliberalism has been characterized by a particularly prominent tendency toward a pragmatic political approach, which is perhaps chiefly represented in Müller-Armack's invention of a 'social market economy' in the immediate postwar period 'as a strategy for transferring the principles of new liberalism into potentially hostile political and societal spheres without neglecting the ultimate objective of creating a new kind of strong state' (Ptak 2009: 123). This pattern of pragmatism, and the aggressively anti-Keynesian and anti-welfare character of their writings, testifies the true authoritarian nature of their political objective. In spite of their distance from a 'pure' Ordoliberal prescription, the recent EU innovations ended up validating in practice the Ordo School's fundamentally anti-democratic goal.

\section{THE ONGOING REFORMS, THE ECONOMIC ALARMISM, AND THE REMAINING FRAGILITY}

By the time the banking crisis and other economic pressures forced the question of further reform onto the agenda, divergences between the economies of the core and periphery within the eurozone had enormously intensified (Storm/Naastepad 2014; O'Connell 2015), changing the political equilibria and nullifying in fact the previous intergovernmental aspirations.

In the absence of a mechanism for risk sharing, the result, inevitably, was a substantial increase in the relative power of the creditors. Interest rates on the bonds of peripheral eurozone countries rocketed upward when they were forced to bail out private banks and financial institutions and the more competitive countries applied different standards of budget surveillance and remediation to their own cases even as they imposed much harsher conditions on their solidarity towards the others.

The European Council of the 25-26 March 2010 instituted the European Financial Stabilization Facility (EFSF), as agreed in a previous meeting between France and Germany. The rescue of Greece was heavily conditioned on the adoption of the policies prescribed by the creditor institutions and, as Pablo Bortz (2015) carefully describes in a recent paper, ' $54 \%$ of the financial assistance provided to Greece was used to repay (foreign) debt, while another $21 \%$ was used to recapitalize Greek banks (some of which were owned by foreign institutions).' Again, in their famous walk at Deauville on 18 October 2010, the German chancellor and the French president once again bypassed the usual EU deliberation procedures and agreed to affirm the no-bail-out principle, now known as Private Sector Involvement, that is the partial bail-in of EMU governments' bond holders. Immediately, Irish and Portuguese bond yields sky-rocketed, followed by Spanish and Italian ones.

In the 1970s, Federico Caffè (1976) developed the concept of economic alarmism, that is, the practice of misrepresenting the economic situation, exaggerating the negative aspects and creating the impression of unprecedented conditions of emergency, as a way to present a certain policy mix, often disruptive of the previous socio-economic equilibrium, as the only possible solution. The Deauville walk brought this principle to the next level, actually generating an emergency that prepared the terrain for a further reform of the SGP that enhanced the power of the Commission against the countries which did not comply with the fiscal rules.

The 2011 reform, the so-called Six Pack Agreement, appeared to be a much tighter framework than the 2005 Pact (Frayne et al. 2013). This in fact is the case - for weaker countries. Those countries whose public debt exceeds the limit must continuously reduce 
it by an average of one-twentieth of the difference between their actual debt-to-income ratio and the 60 percent of GDP. This is calculated either over the previous three years (a backward-looking benchmark) or, if such a target is not met, against the Commission's forecasts (a forward-looking benchmark). Mitigating conditions can be invoked to take account of the effects of the cycle and of exceptional circumstances. The agreement fixes the structural budget constraint at 0.5 percent of GDP and also envisages the possibility of early sanctions (interest- and non-interest-bearing deposits) for repeated noncompliance with the Commission's rules, in cases of 'significant deviation from Medium Term Objectives.'

However, as we will see, what the recent reforms have made stricter is, rather, the explicit control of the supranational European institutions over a comprehensive range of macroeconomic and institutional practices of member countries, while maintaining flexible and asymmetric implementation of the rules. In fact, the exceptions included in the 2005 Pact still hold with even some additions, including the 'case of unusual events outside the control of the country with a major impact on the financial position of the general government' and the 'case of severe economic downturn in the euro area or the union as a whole.' ${ }^{\prime}$ The heavy reliance on estimates of potential output and cyclically adjusted budget measures is still present in the Six Pack Agreement: not only are most constraints expressed in structural budget terms, but the Six Pack has also created a new Expenditures Benchmark to assess whether structural expenditures progress is in line with the mediumterm potential output (Frayne et al. 2013, p. 13). The folly of all this is well illustrated by the potential output and NAWRU figures for several peripheral countries.

But reliance on structural budget and potential output estimates does not exhaust the new macroeconomic supervisory aspirations of the European institutions. The 2011 reforms have explicitly transformed the European fiscal framework into a wider system of Economic Governance (European Commission 2014) that applies asymmetrically to member countries, depending on their financial fragility. This shift started with the definition of the European Semester that sets up a common timeline for the Commission's macroeconomic evaluation and recommendations based on an Annual Growth Survey published by the same institution, which requires the countries to report and comply with its indications.

The Six Pack also established a new Macroeconomic Imbalance Procedure running alongside the provisions of the Stability and Growth Pact and relying on similar mechanisms (European Commission 2012). The indicators used in the macroeconomic evaluations apply less mechanically than the constraints of the SGP and take account of several external and internal dimensions: current-account position (between +6 percent and -4 percent of GDP), net investment position, nominal unit labor costs, real effective interest rates, private sector debt (160 percent of GDP), private sector credit flows, house prices, public sector debt (60 percent of GDP), unemployment rates (10 percent threeyear average), and total financial liabilities of the financial sector.

The dizzying stream of numbers clashes with all attempts to plan intelligently, while the degree of interference with national plans can be very high. For instance, the rescue programs (the temporary European Financial Stability Facility, the permanent European Stability Mechanism, and the smaller European Financial Stabilization Mechanism) depend on a strict conditionality, with the IMF playing a crucial role. According to the 2013 Two Pack regulation, countries within a program of the European Stability Mechanism are subject to enhanced surveillance and to formal post-program surveillance. The latter concerns countries

9. In January 2015, at the end of the Italian presidency of the Council, the Commission issued a new guidance to its application of the existing rules, specifying the implementation of the investment,' 'structural reform,' and 'cyclical conditions' clauses. 
emerging from adjustment programs as well as precautionary assistance and lasts until they have paid back at least 75 percent of the assistance received.

Furthermore, countries "whose difficulties could have "significant adverse effects" on the rest of the euro area can be asked to prepare full macroeconomic adjustment programs. These programs are subject to quarterly review missions and strict conditions in exchange for financial assistance' (European Commission 2014).

Strict conditionality applies to the operations of the ECB as well, whose policies have saved the eurozone from failing but has also, at times, taken advantage of its position to push for specific political outcomes. ${ }^{10}$ However, the absence of a political desire to create an automatic insurance mechanism emerges again in the context of the creation of a banking union, a process started in 2012 and which is still ongoing. Today, the process worryingly recalls the events of 2010 that brought about the SGP reform.

\section{CONCLUSIONS}

The content of the Commission's prescriptions to the member countries depends on the formulation of statistical estimates and on their political interpretation, relying on a shaky theoretical approach. The national governments, in this period of crisis, have acted as executors of those interpretations. The conditions they are asked to fulfill have involved structural reforms regarding all levels of education, health care, labor rights, and political institutions, as well as changes in the tax structure and even budget cuts.

The presence of rules in this system is crucial: discretionary measures need to go through the various democratic stages of decision and thus leave plenty of time and room for a political discussion over their costs and benefits. By contrast, compliance with a fixed formula simplifies negotiations each time a measure is proposed. Budgetary decisions appear as a routine act and a certain distance is created between them and contingent political matters. This is especially true in the case of the EU, where the definition of the rule is not the responsibility of the national governments.

But in this context, the use of structural rather than nominal targets has represented an evolution away from 'pure' Ordoliberal rhetoric, in favor of a degree of pragmatic flexibility toward specific interests during crises while retaining a disciplinary argument. In fact, the Commission's formula for the cyclically adjusted budget reflects the new comprehensive way in which fiscal policy has come to be interpreted since the 1980 s, meanwhile rejecting, by assumption, the idea of contractionary effects via a reduction of aggregate demand. Hence the cyclically adjusted budget works as an $e x$ post justification for further austerity, locking Europe into a vicious spiral. But, because of its ad hoc construction, it also lends itself to allowing temporary exceptions of a political nature.

This cyclically adjusted budget formula, it is worth remembering, is similar to those used by most national and international agencies. They have been widely recognized to be weak and flimsy both theoretically and empirically by economists of different schools and traditions. The formula is based, for instance, on empirically suspect assumptions

10. For the sake of conciseness, this paper neglects the influence of the ECB on the latest evolutions. However, its role deserves at least some mention, because not only in the absence of its Quantitative Easing programmes the whole EU construction would have crumbled, making any legislative innovation impossible, but also it has been an active player (or maybe an arbitrator) creating conditions and pressures sometimes in agreement with the other institutions and sometimes in divergence. See the paper by Mario Seccareccia (2017) in this issue for the dedicated discussion. 
regarding the supply-side determination of the equilibrium and the existence of a direct and stable relation between output gaps and inflation. Such estimates fail to provide indicators of the size of the automatic stabilizers and the sustainability of a budget policy; the estimates are very sensitive to updates to the time series used in the calculation and hence are subject to continuous and significant ex post revision (Costantini 2015).

National constitutions and parliaments, crucial to the post-war European democracies, are becoming increasingly useless. These democracies represented the attempt, after the totalitarian experiences of the previous decades, to build institutional guarantees for the maintenance of well-balanced democratic representation and resolution of political and economic interests. The locus of political negotiation, instead, increasingly resides in technocratic committees. The latter are becoming the instruments that resolve the tensions between the diverse national elite groups.

This is the context in which the discussion on the opportunity of a fiscal union takes place. Of course, a fiscal union would not guarantee that austerity is not implemented within the various regions and that a similar core-periphery system is perpetuated, but it would solve the problem of multiple conflicting authorities. On the one hand, the accomplishment of a stable central EU power may lead to much greater flexibility - as the New Consensus prescribes. On the other, it might result in an explicit and definitive exclusion of any democratic authority over fiscal policy.

\section{REFERENCES}

Bellofiore, R., Halevi, J. (2011): It could be raining: the European crisis after the Great Recession, in: International Journal of Political Economy, 39(4), 5-30.

Blanchard, O.J. (1993): Suggestions for a new set of fiscal indicators, OECD Economics Department Working Paper, No 79.

Blanchard, O.J., Giavazzi, F. (2004): Improving the SGP through a proper accounting of public investment, International Macroeconomics, CEPR Discussion Papers, No 4220.

Blinder, A.S., Solow, R.M. (1974): Analytical foundations of fiscal policy, in: Blinder, A.S. (ed.), The Economics of Public Finance, Studies of Government Finance, Washington, DC: The Brookings Institution, 3-115.

Bortz, P.G. (2015): The Greek 'rescue': where did the money go? An analysis, Institute for New Economic Thinking Working Paper, No 29, URL: http://ineteconomics.org/uploads/papers/ WP29-Bortz.pdf.

Caffe, F. (1976): Un'economia in ritardo: contributi alla critica della recente politica economica italiana, Turin: Bollati Boringhieri.

Canterbery, A.R. (1968): Economics on a New Frontier, Belmont, CA: Wadsworth.

CED (Committee for Economic Development) (1944): Post-War Federal Tax Plan for High Employment, New York: CED Research Committee.

CED (Committee for Economic Development) (1947): Taxes and the Budget: A Program for Prosperity in a Free Economy, New York: CED Research Committee.

Ciccone, R. (2013): Public debt and aggregate demand: some unconventional dynamics, in: Levrero, E.S., Palumbo, A., Stirati, A. (eds), Sraffa and the Reconstruction of Economic Theory, London: Palgrave Macmillan, 15-43.

Costantini, O. (2015): Cyclically adjusted budget: history and exegesis of a fateful estimate, Institute for New Economic Thinking Working Paper, No 24. URL: http://ineteconomics.org/uploads/ papers/WP24-Costantini.pdf.

Costantini, O. (2018): Invented in America: birth and evolution of the cyclically adjusted budget rule, 1933-1961, History of Political Economy, 50(1), forthcoming.

De Masi, P.R. (1997): IMF estimates of potential output: theory and practice, in: Staff Studies for the World Economic Outlook, IMF, 40-46. 
European Commission (1993): Growth, competitiveness, employment: the challenges and ways forward into the 21 st century, White Paper, 5 December.

European Commission (2002): Communication from the Commission to Council and the European Parliament: Strengthening the Co-ordination of Budgetary Policies, Brussels.

European Commission (2004): Public Finances in EMU, Brussels.

European Commission (2005a): Public Finances in EMU, Brussels.

European Commission (2005b): New and Updated Budgetary Sensitivities for the EU Budgetary Surveillance, Directorate General Economic and Financial Affairs, EU Commission.

European Commission (2012): Second Alert Mechanism report on macroeconomic imbalances in EU Member States, Memo, Brussels, 28 November.

European Commission (2014): The EU's economic governance explained, Memo, Brussels, 28 May.

European Council (2005): Presidency Conclusions, Brussels.

Fatàs, A., Mihov, I. (2010): The euro and fiscal policy, in: Alesina, A., Giavazzi, F. (eds), Europe and the Euro, Chicago: Chicago University Press, 287-324.

Felipe, J., McCombie, J.S.L. (2007): Is a theory of total factor productivity really needed?, in: Metroeconomica, 58(1), 195-229.

Felipe, J., McCombie, J.S.L. (2013): The Aggregate Production Function and the Measurement of Technical Change: 'Not Even Wrong', Cheltenham, UK and Northampton, MA: Edgar Elgar.

Frayne, C., Jaffee, E., Riso, S. (2013): Building a strengthened fiscal framework in the European Union: a guide to the Stability and Growth Pact, European Economy, Occasional Paper, No 150.

Galbraith, J.K. (1997): Time to ditch the NAIRU, in: The Journal of Economic Perspectives, 11(1), 93-108.

Garbellini, N. (2015): Small fiscal multipliers do not justify austerity: a macroeconomic accounting analysis of public debt-to-GDP dynamics, MPRA Paper, No 6223.

Giovannini Group (2000): Coordinated debt issuance in the euro area, Report, 8 November.

Girouard, N., André, C. (2005): Measuring cyclically-adjusted budget balances for OECD countries, OECD Economics Department Working Paper, No 434.

Godley, W. (1992): Maastricht and all that, in: London Review of Books, 14(19), 2-3. (Reprinted in: Lavoie, M., Zezza, G. (eds) (2012): The Stock-flow Consistent Approach: Selected Writings of Wynne Godley, Basingstoke, UK: Palgrave Macmillan, 189-193.)

Goodhart, C.A.E. (1998): The two concepts of money: implications for the analysis of optimal currency areas, in: European Journal of Political Economy, 14(3), 407-432.

Gordon, R.J. (1997): The time-varying NAIRU and its implications for economic policy, in: Journal of Economic Perspectives, 11(1), 11-32.

Halevi, J. (2016): France as the epicenter of austerity: sympathetic thoughts about Parguez's contribution on the origins of the euro, in: International Journal of Political Economy, 45(1), 17-24.

Havik, K., McMorrow, K., Orlandi, F., Planas, C., Raciborski, R., Röger, W., Rossi, A., ThumThysen, A., Vandermeulen, V. (2014): The production function methodology for calculating potential growth rates and output gaps, European Commission Directorate-General for Economic and Financial Affairs Economic Paper, No 535.

Hodrick, R.J., Prescott, E.C. (1981): Postwar U.S. business cycles: an empirical investigation, Northwestern University-Center for Mathematical Studies in Economics and Management Science Discussion paper, No 451.

Holland, S. (2014): Europe in Question: And What to Do about It, Nottingham, UK: Spokesman Books.

Holland, S., Varoufakis, Y. (2011): A modest proposal for overcoming the euro crisis, Levy Economics Institute of Bard College, Policy Note, No 3.

Kindleberger, C.P. (1996): Centralization versus Pluralism: A Historical Examination of PoliticalEconomic Struggles and Swings within Some Leading Nations, Copenhagen: Copenhagen Business School Press.

Larch, M., Turrini, A. (2009): The cyclically adjusted budget balance in EU fiscal policy making: a love at first sight turned into a mature relationship, European Economy, Directorate-General for Economic and Financial Affairs Economic Paper, No 374. 
Lavoie, M. (2015): The eurozone: similarities to and differences from Keynes's plan, in: International Journal of Political Economy, 44(1), 3-17.

Little, A. (2012): Did Germany sow the seeds of the eurozone debt crisis?, BBC News, URL: http:// www.bbc.com/news/world-europe-16761087 (accessed 29 January 2012).

Lucarelli, S. (2015): Mario Draghi, in: Rochon, L.-P., Rossi, S. (eds), The Encyclopedia of Central Banking, Cheltenham, UK and Northampton, MA: Edgar Elgar, 150-152.

Monnet, J. (1976): Mémoires, Paris: Librairie Arthème Fayard.

Mourre, G., Isbasoiu, G., Paternoster, D., Salto, M. (2013): The cyclically-adjusted budget balance used in the EU fiscal framework: an update, European Commission Directorate-General for Economic and Financial Affairs Economic Papers, No 478.

Mourre, G., Astarita, C., Princen, S. (2014): Adjusting the budget balance for the business cycle: the EU methodology, European Commission Directorate-General for Economic and Financial Affairs Economic Paper, No 536.

O'Connell, A. (2015): European crisis: a new tale of center-periphery relations in the world of financial liberalization/globalization? in: International Journal of Political Economy, 44(3), $174-195$

Palumbo, A. (2013): Potential output and demand-led growth, in: Levrero, E.S., Palumbo, A., Stirati, A. (eds), Sraffa and the Reconstruction of Economic Theory, London: Palgrave Macmillan, 92-119.

Parguez, A. (1999): The expected failure of the European economic and monetary union: a false money against the real economy, in: Eastern Economic Journal, 25(1), 63-76.

Parguez, A. (2016): Economic theories of social order and the origins of the euro, in: International Journal of Political Economy, 45(1), 2-16.

Pasinetti, L. (2000): Critica della teoria neoclassica della crescita e della distribuzione, in: Moneta e Credito, 53(210), 187-232.

Ptak, R. (2009): Neoliberalism in Germany, in: Mirowski, P., Plehwe, D. (eds), The Road from Mont Pelerin: The Making of the Neoliberal Thought Collective, Cambridge, MA: Harvard University Press, 98-137.

Reiermann, C., Wiegrefe, K. (2012): Chancellor Schröder's legacy: Germany's leading role in weakening the euro, in: Spiegel International, URL: http://www.spiegel.de/international/germany/ chancellor-gerhard-schroeder-key-in-weakening-the-euro-stability-pact-a-844458.html (accessed 16 July 2012) (originally appeared in German in Der Spiegel, issue 29/2012, 16 July 2012).

Schmitt, C. (1931 [2015]): The development of parliament into the arena of a pluralistic system, in: Vinx, L. (ed.), The Guardian of the Constitution, Cambridge, UK: Cambridge University Press, $125-146$.

Seccareccia, M., Correa, E. (2015): Supra-national money and the euro crisis: lessons from Karl Polanyi, in: Forum for Social Economics, doi: 10.1080/07360932.2015.1075896.

Seccareccia, M. (2017): Is high employment in the eurozone possible? Some reflections on the institutional structure of the eurozone and its crisis, in: European Journal of Economics and Economic Policies: Intervention, 14(3), 351-371.

Simonazzi, A., Vianello, A. (1999): Liberalizzazione finanziara, moneta unica europea e occupazione, in: Pizzuto, F.R. (ed.), Globalizzazione, Istituzioni e Coesione Sociale, Cantazaro: Meridiana, $227-253$.

Storm, S., Naastepad, C.W.M. (2012): Macroeconomics beyond the NAIRU, Cambridge, MA: Harvard University Press.

Storm, S., Naastepad, C.W.M. (2014): Europe's hunger games: income distribution, cost competitiveness and crisis, in: Cambridge Journal of Economics, 39(3), 959-986.

Sylos Labini, P. (1995): Why the interpretation of the Cobb-Douglas production function must be radically changed, in: Structural Change and Economic Dynamics, 6(4), 485-504.

Story, L., Landon, T.J., Schwartz, N. (2010): Wall St. helped to mask debt fueling Europe's crisis, in: The New York Times, URL: http://www.nytimes.com/2010/02/14/business/global/14debt. html?pagewanted=all (accessed 13 February 2010).

Thirlwall, A.P. (2014): Economic Growth in an Open Developing Economy, Cheltenham, UK and Northampton, MA: Edward Elgar. 
Truger, A. (2014): Austerity, cyclical adjustment and the remaining leeway for expansionary fiscal policies in the euro area, Macroeconomic Policy Institute (IMK) Working Paper, No 140, Düsseldorf: IMK.

Villeroy de Galhau, F., Weidmann, J. (2016): Europa braucht mehr Investitionen, in: Süddeutsche Zeitung, 8 February, URL: http://www.sueddeutsche.de/wirtschaft/euro-raum-europa-brauchtein-gemeinsames-finanzministerium-1.2852586.

Vinx, L. (2015): Introduction, in: Vinx, L. (ed.), The Guardian of the Constitution, Cambridge, UK: Cambridge University Press, 1-21. 